\title{
Research on the Impact of Corporate Philanthropy on Employer Brand
}

\author{
Yaqing Zhang ${ }^{1}$, Jihong $\mathrm{Wu}^{2, *}$, Guiqing $\mathrm{Li}^{1}$, Jingyu $\mathrm{Fu}^{1}$, Chizhou $\mathrm{Zhu}^{1}$ and $\mathrm{Jie} \mathrm{Liu}^{1}$ \\ ${ }^{I}$ School of Management, Chengdu University of Information Technology, Chengdu, Sichuan610103, China \\ ${ }^{2}$ School of Management and Economics of UESTC, University of Electronic Science and Technology of China, Chengdu, \\ Sichuan 611731, China \\ *Corresponding author.Email: wujh@uestc.edu.cn
}

\begin{abstract}
To study the impact of corporate philanthropy on employer brand, this paper collects employer brand data for 2020 and corporate philanthropy data for 2018 for empirical research. The results of linear regression analysis are as follows: (1) the operating life of the corporate charitable foundation has a positive impact on the employer brand; (2) corporate advertising investment has a positive impact on employer brand; and (3) when the enterprise carries out both charitable donations and advertising, it will have a negative impact on the employer brand. From this, we can conclude that charitable foundations help companies build employer brands. In addition, to avoid malicious speculation about charitable motives that negatively affect the employer's brand, companies should pay attention to the planning of charity strategy and advertising marketing strategy. This study opens a new perspective for corporate philanthropy strategic planning and broadens the direction for corporate employer brand building.

Keywords: Charitable donation, Charitable foundations, Employer brand, Advertising investment
\end{abstract}

\section{INTRODUCTION}

In recent years, China's philanthropy has developed rapidly, and more and more enterprises have devoted themselves to public welfare and charity. As the highest manifestation of corporate social responsibility, charity can improve the distribution pattern of income and wealth. in addition, it is of great significance in organizing market resources, regulating the gap between the rich and the poor, easing social conflicts and promoting social equity. Therefore, it is very necessary for enterprises to develop charity.

As for the research on charitable behavior, Liket \& Simaens (2015) believes that corporate philanthropy is divided into multiple levels, including individuals, organizations, institutions and the combination of these different levels [1]. From different levels, corporate philanthropy has different motivations, implementation methods, and social consequences. However, most of the current research on corporate philanthropy at the individual level focus on the decision-making of senior leaders, while few researches on employees of enterprises. Employees are important internal stakeholders of an enterprise. Employer brand is the result of employee relationship, corporate culture and business strategy, and it is a significant feature that distinguishes a company from its competitors and a key factor for an enterprise to gain competitiveness in the labor market [2]. Employer brand plays an important role in attracting potential employees and retaining existing employees [3].
At present, most academic studies mainly focus on the motivation and economic consequences of charitable donation, and relatively few studies on the relationship between corporate philanthropy and employer brand. Therefore, this paper carries out an empirical study on the influence of corporate philanthropy on employer brand and its influence mechanism. In this paper, a-share listed companies in 2020 are selected as research samples to empirically analyze the relationship between corporate philanthropy and employer brand. Based on the signaling theory, advertising input is introduced as a moderating variable to verify its impact on the relationship between corporate philanthropy and employer brand. This paper provides a new idea for enterprises to formulate charity strategic plan and marketing strategy.

\section{THEORETICAL ANALYSIS AND RESEARCH HYPOTHESIS}

\subsection{Corporate Philanthropy}

Corporate philanthropy is generally defined as the voluntary provision of resources by a company to other organizations or individuals, mainly in the form of money, time or expertise, for the purpose of improving public social interests [4]. Charity is also an important way for enterprises to fulfill their social responsibilities. In the research of this paper, corporate charitable donation and 
the establishment of charitable foundations together constitute corporate charitable behavior.

The impact of corporate philanthropy is not limited to the organizational level and the level of senior leaders. It is also relevant to the average current and potential employee. Breeze \& Wiepking (2020) found that: Employee participation in philanthropic activities can help maximize the impact of corporate philanthropy on the company's social advantage. In addition, philanthropic activities that are considered "valuable" by employees and relevant to the lives of most of their colleagues can trigger collective empathy, which in turn improves employee morale and contributes to the achievement of corporate goals [5]. The study of Lee et al. (2014) believed that corporate philanthropy would affect employee engagement and turnover intention, so enterprises should take philanthropy as a strategy to retain employees and maintain sustainable development [6]. The research of Arco-Castro et al. (2020) believes that a company's philanthropic strategy will affect the attitude of employees, and the corporate philanthropic approach can highlight and define the corporate image and help cultivate trust among employees [7]

\subsection{Corporate Philanthropy and Employer Branding}

Employer brand was first proposed by Ambler \& Barrow (1996), who believed that employer brand is reflected in the combination of functional, economic and psychological benefits associated with the employer in the employment behavior [8]. Russell \& Brannan (2016) proposed that employer brand is constructed by embedding HRM practices [9]. Lievens \& Highhouse (2003) divided employer brand into instrumental dimension and symbolic dimension[10]. The instrumental dimension is more embodied by tangible HRM practices, including salary, promotion opportunities, benefits, work busy, work location, and job stability; The symbolic dimension is more represented by intangible organizational personality traits or external images, including innovation, sincerity, reputation, ability, and strength.

Employer brand is an organizational image perceived by employees, shareholders and other stakeholders, which reflects corporate culture, attitude and employee relationship. Talent competition is one of the important competitions faced by enterprises. The unique employer brand can surpass the enterprise brand and become a new concept and new tool to make the organization stand out in the talent competition [11]. According to Sivertzen et al. (2013), employer brand is not only positively correlated with company image, but also positively correlated with applicants' intention to apply for the company [12]. In addition to its attractive effect on potential employees, employer brands can help retain skilled employees, reduce the cost of organizational talent[13], improve the match between employees and the organization, and help improve employee engagement [14], Improve employees' commitment, satisfaction, performance and loyalty to the organization[15].

A good corporate image of social responsibility can improve job seekers' interest in the enterprise [16]. Ozcan \& Elci (2020) found that employee-oriented CSR helps to establish employees' positive perception of corporate brand image and has a positive impact on the establishment of a strong employer brand [17]. At present, most academic studies mainly focus on the motivation and economic consequences of charitable donation, and relatively few studies on the relationship between charity and employer brand. According to the theory of enterprise value chain, enterprise's charitable behavior will bring employees a good perception of enterprise value culture. This helps to increase the emotional value of employees to the company and has a positive impact on the employer brand.

Based on the above discussion, hypotheses are proposed:

H1: Corporate philanthropy has a positive impact on employer brands.

\subsection{The Moderating Effect of Advertising Spending}

According to the signal transmission theory, due to the asymmetry of market information, there is poor information between enterprises and stakeholders. In order to achieve the corresponding purpose, enterprises will transmit information about enterprises to stakeholders. Advertising is a concrete signal that can convey a business message. Nakao (1993) found that the advertising expenditure of enterprises can effectively improve the value of corporate goodwill [18]. Rinallo \& Basuroy (2009) believed that the advertising investment of enterprises affected the favorable reports of the media on the company [19]. According to the study of Collins \& Han (2004), corporate advertisements have a direct impact on both the quantity and quality of job seekers [20]. Companies investing in advertisements can not only attract more consumers, but also gain competitive advantages in the competition for talents. To enhance the employer brand, companies use advertising to inform job seekers and current employees about corporate philanthropy.

Based on the above conclusions, the following hypotheses are proposed:

$\mathrm{H} 2$ : Advertising investment will enhance and regulate the positive impact of corporate philanthropy on employer brand.

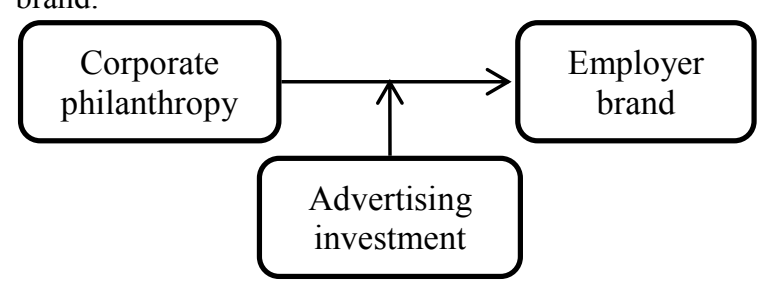

Figure 1. theoretical model 


\section{STUDY DESIGN}

\subsection{Sample Selection and Data Sources of This Option}

This paper adopts panel data, selects listed companies in 2018 as samples, and conducts screening according to certain conditions: excluding financial industry and ST companies; excluding the listed companies with missing data, 184 observations were finally obtained. Corporate philanthropy and advertising spending data came from the CSMAR database, while employer brand data came from Kanzhun.com. In order to eliminate the influence of extreme values, the continuous variables with outliers were treated with $1 \%$ quantile tail reduction. Considering the lag effect of corporate philanthropy on employer brand, the data of corporate philanthropy and advertising investment in 2018 and the data of employer brand in 2020 is used for two years of lag processing. This article deals with data primarily using Excel and Stata software.

\subsection{Definition of Quantitative Variables}

(1) Explanatory variables: In order to ensure the strictness of the article, charitable donations and charitable foundations were selected as explanatory variables in this paper. Charitable donation was measured by dividing the amount of charitable giving by the total fixed assets of the enterprise in 2018. Charitable foundations are expressed by the number of years established by enterprises up to 2018 .

(2) Explained variable: The explained variable of this paper is employer brand. The data comes from the average score of five dimensions in the radar chart of "Company Score" in January 2021: salary and benefits, working conditions, work-life balance, company identity and career development.

(3) Moderating variable: The moderating variable of this paper is advertising investment, which is measured by investment amount. The data came from the CSMAR database of notes to the financial statements of listed companies, and was obtained through manual sorting. The data and conclusions are logarithmically processed for accuracy.

(4) Control variables: In this paper, enterprise scale and enterprise nature are selected as control variables.

Table 1. Variable definition table

\begin{tabular}{|l|l|l|}
\hline $\begin{array}{l}\text { Variables } \\
\text { name }\end{array}$ & Symbol & Variables definition \\
\hline $\begin{array}{l}\text { Charitable } \\
\text { donation }\end{array}$ & don & $\begin{array}{l}\text { Charitable Donation } \\
\text { amount/Fixed total Assets }\end{array}$ \\
\hline $\begin{array}{l}\text { Charitable } \\
\text { foundation }\end{array}$ & charity & $\begin{array}{l}\text { by 2018, Enterprise } \\
\text { charitable Foundation } \\
\text { operating years }\end{array}$ \\
\hline $\begin{array}{l}\text { Employer } \\
\text { brand }\end{array}$ & EB & $\begin{array}{l}\text { Company score in the } \\
\text { network }\end{array}$ \\
\hline
\end{tabular}

\begin{tabular}{|l|l|l|}
\hline $\begin{array}{l}\text { Advertising } \\
\text { investment }\end{array}$ & $\ln \mathrm{AI}$ & $\begin{array}{l}\ln (1+\text { advertising } \\
\text { investment })\end{array}$ \\
\hline $\begin{array}{l}\text { Enterprise } \\
\text { scale }\end{array}$ & Size & $\ln (1+$ total fixed assets $)$ \\
\hline $\begin{array}{l}\text { Enterprise } \\
\text { nature }\end{array}$ & Ownership & $\begin{array}{l}\text { 0 indicates a non-state- } \\
\text { owned enterprise, and 1 } \\
\text { indicates a state-owned } \\
\text { enterprise }\end{array}$ \\
\hline
\end{tabular}

\subsection{Model Design}

In order to test the relationship between corporate philanthropy and employer brand, the following models are constructed:

$$
E B=\alpha_{0}+\alpha_{1} \text { don }+\alpha_{2} \text { charity }+\alpha_{3} \text { Control }+\mu
$$

To test the moderating effect of Advertising investment on the relationship between corporate philanthropy and employer brand, the following models are constructed: $E B=\beta_{0}+\beta_{1}$ don $+\beta_{2}$ charity $+\beta_{3} \operatorname{LnAI}+\beta_{4}$ don $\times$ LnAI $+\beta_{5}$ charity $\times \operatorname{LnAI}+\beta_{6}$ Control $+\varepsilon$

\section{EMPIRICAL AND RESULTS ANALYSIS}

\subsection{Descriptive Statistics}

Table 2 shows the descriptive statistical results of the main variables. The maximum value of charitable donation was 0.154 , the minimum value was 0 , and the mean value was 0.005 , indicating that there was a great difference between enterprises in charitable donation and donation amount. The minimum and maximum operating years of charitable foundations were 0,11 , and 0.583 , indicating that the majority of enterprises did not establish foundations or foundations established in a short period of time. The difference between the mean value of employer brand and $50 \%$ point value is small, indicating that the distribution is basically normal. The small difference between the mean value and $50 \%$ point value indicates that the distribution is basically normal. Division of enterprise scale is more uniform, the gap is not significant. The number of private enterprises and state-owned enterprises is basically equal.

Table 2. Summary table Descriptive statistics

\begin{tabular}{|l|c|c|c|c|c|c|}
\hline Variable & N & Mean & p50 & sd & min & max \\
\hline Don & 184 & 0.00500 & 0 & 0.0230 & 0 & 0.154 \\
\hline Charity & 184 & 0.538 & 0 & 1.873 & 0 & 11 \\
\hline Eb & 184 & 3.378 & 3.420 & 0.352 & 2.340 & 4.140 \\
\hline Lnai & 184 & 8.049 & 8.139 & 2.473 & 2.989 & 13.91 \\
\hline Size & 184 & 23.68 & 23.62 & 1.460 & 20.75 & 27.57 \\
\hline Ownership & 184 & 0.489 & 0 & 0.501 & 0 & 1 \\
\hline
\end{tabular}




\subsection{Correlation Coefficients}

Table 3 reports Pearson correlation analysis of the main variables. Pearson correlation analysis of the main variables is reported in Table 3. From the table, it can be preliminarily concluded that there is no significant relationship between corporate charitable donation and employer brand. The correlation coefficient between charitable foundations and employer brands was 0.143 and passed the significance test at the $10 \%$ level. The correlation coefficient between advertising input and employer brand is 0.284 , which is significant at $1 \%$ level, indicating a significant positive correlation between advertising input and employer brand. Both firm size and firm nature have a significant positive impact on employer brand.

Table 3. Relationship table Correlation coefficient table

\begin{tabular}{|l|l|l|l|l|l|l|}
\hline Variables & $(\mathbf{1})$ & $\mathbf{( 2 )}$ & $\mathbf{( 3 )}$ & $\mathbf{( 4 )}$ & $\mathbf{( 5 )}$ & $\mathbf{( 6 )}$ \\
\hline (1) don & 1.000 & & & & & \\
\hline (2) charity & $0.156^{* *}$ & 1.000 & & & & \\
\hline (3) EB & 0.011 & $0.143^{*}$ & 1.000 & & & \\
\hline (4) lnAI & 0.119 & 0.103 & $0.284^{* * *}$ & 1.000 & & \\
\hline (5) size & 0.090 & $0.223^{* * *}$ & $0.247^{* * *}$ & $0.550^{* * *}$ & 1.000 & \\
\hline (6) ownership & $-0.203^{* * *}$ & -0.113 & $0.165^{* *}$ & $0.179^{* *}$ & $0.333^{* * *}$ & 1.000 \\
\hline
\end{tabular}

\subsection{Regression Analysis}

As shown in the table, models (1) (3) show the regression result of corporate philanthropy to employer brand. The control variables size and ownership are added into model (1).The results show that there is a significant positive relationship between firm size and employer brand. The bigger the company, the better the employer brand building. There is no significant relationship between firm nature and employer brand.

Model (2) adds independent variables -- charitable amount and charitable foundation on the basis of Model (1). The results showed no significant relationship between the amount of charitable giving and employer brand. The results of charitable foundations' variable correlation showed that the correlation coefficient was 0.022 , which passed the significance test at the $10 \%$ level. There was a significant positive correlation between the foundation's operating years and the employer's brand. Hypothesis 1 is partially verified.

On the basis of model (2), model (3) adds moderating variable advertising investment and the interaction term between advertising input and corporate philanthropy. The results show that the correlation coefficient between advertising investment and employer brand is 0.033 , passing the significance test at the level of $5 \%$, indicating that advertising investment has a very significant effect on employer brand. The correlation coefficient between the interaction term of charitable donation and advertising investment and employer brand is -0.866 , passing the significance test at the level of $5 \%$, indicating that advertising investment and charitable donation together exert a negative impact on employer brand.

\subsection{Robustness Test}

In order to avoid the influence of omitted variables on the conclusion of the paper, age, lnstaff and proportion of independent directors were added into the regression analysis of the model. The main regression results were consistent with Table 4, and the research conclusions did not change, indicating that the model was robust.

Table 4. Regressive analysis table

\begin{tabular}{|c|c|c|c|}
\hline & $\begin{array}{l}\text { (1) } \\
\text { EB }\end{array}$ & $\begin{array}{l}\text { (2) } \\
\text { EB }\end{array}$ & $\begin{array}{l}\text { (3) } \\
\text { EB }\end{array}$ \\
\hline \multirow{2}{*}{ size } & $0.052^{* *}$ & $0.044^{*}$ & 0.018 \\
\hline & $(0.018)$ & $(0.019)$ & $(0.021)$ \\
\hline \multirow{2}{*}{ ownership } & 0.066 & 0.083 & 0.075 \\
\hline & $(0.053)$ & $(0.054)$ & $(0.054)$ \\
\hline \multirow{2}{*}{ don } & & 0.009 & 0.810 \\
\hline & & $(1.346)$ & $(1.228)$ \\
\hline \multirow{2}{*}{ charity } & & $0.022^{*}$ & $0.028^{* *}$ \\
\hline & & $(0.010)$ & $(0.010)$ \\
\hline \multirow{2}{*}{$\ln \mathrm{AI}$} & & & $0.033^{* *}$ \\
\hline & & & $(0.012)$ \\
\hline \multirow{2}{*}{ don* $\ln A \mathrm{I}$} & & & $-0.866^{* *}$ \\
\hline & & & $(0.286)$ \\
\hline \multirow{2}{*}{ charity*lnAI } & & & -0.005 \\
\hline & & & $(0.003)$ \\
\hline \multirow{2}{*}{ cons } & $2.113^{* * *}$ & $2.288^{* * *}$ & $2.640^{* * *}$ \\
\hline & $(0.422)$ & $(0.448)$ & $(0.453)$ \\
\hline$N$ & 184 & 184 & 184 \\
\hline
\end{tabular}


Table 5. Robustness test analysis table

\begin{tabular}{|c|c|c|c|}
\hline & $\begin{array}{l}\text { (1) } \\
\text { EB }\end{array}$ & $\begin{array}{l}\text { (2) } \\
\text { EB }\end{array}$ & $\begin{array}{l}\text { (3) } \\
\text { EB }\end{array}$ \\
\hline \multirow{2}{*}{ size } & $0.071^{*}$ & $0.066^{*}$ & 0.052 \\
\hline & $(0.029)$ & $(0.030)$ & $(0.029)$ \\
\hline \multirow{2}{*}{ ownership } & 0.069 & 0.087 & 0.087 \\
\hline & $(0.052)$ & $(0.054)$ & $(0.053)$ \\
\hline \multirow{2}{*}{ age } & 0.000 & -0.001 & -0.004 \\
\hline & $(0.006)$ & $(0.006)$ & $(0.006)$ \\
\hline \multirow{2}{*}{ lnstaff } & -0.027 & -0.032 & -0.059 \\
\hline & $(0.034)$ & $(0.034)$ & $(0.034)$ \\
\hline \multirow{2}{*}{ RID } & 0.164 & 0.171 & -0.004 \\
\hline & $(0.362)$ & $(0.364)$ & $(0.378)$ \\
\hline \multirow{2}{*}{ don } & & -0.203 & 0.345 \\
\hline & & $(1.337)$ & $(1.213)$ \\
\hline \multirow{2}{*}{ charity } & & $0.023^{*}$ & $0.031^{* *}$ \\
\hline & & $(0.011)$ & $(0.010)$ \\
\hline \multirow{2}{*}{$\ln \mathrm{AI}$} & & & $0.041^{* * *}$ \\
\hline & & & $(0.012)$ \\
\hline \multirow{2}{*}{$\operatorname{don} 2 * \ln A I$} & & & $-0.797^{* *}$ \\
\hline & & & $(0.285)$ \\
\hline \multirow{2}{*}{ charity* $\ln \mathrm{AI}$} & & & -0.005 \\
\hline & & & $(0.003)$ \\
\hline \multirow{2}{*}{ _cons } & $1.847^{* * *}$ & $2.001^{* * *}$ & $2.373^{* * * *}$ \\
\hline & $(0.500)$ & $(0.532)$ & $(0.528)$ \\
\hline$N$ & 184 & 184 & 184 \\
\hline
\end{tabular}

\section{CONCLUSION AND REVELATION}

\subsection{Research Conclusion}

This paper selects non-financial listed companies in 2020 as research samples to explore the impact of corporate philanthropy on employer brand, and analyzes whether advertising investment has a moderating effect on this mechanism. The empirical results show that: (1) there is a significant positive correlation between the operating years of corporate charitable foundations and employer brand, that is, the longer the establishment of charitable foundations, the stronger the positive impact on employer brand.(2) Advertising investment has a significant positive impact on employer brand.(3) When enterprises make charitable donations and invest in advertising at the same time, it will have a negative impact on the employer brand. In view of the conclusion (3), the attribution theory shows that enterprise independently advertising and marketing, will improve enterprise's popularity, make enterprise potential employees and other external stakeholders of corporate culture and value concept, has certain positive understanding, but when the charitable donations to appear at the same time, would be considered more high-profile enterprise, to question the motives of the charity, It is hypocritical to suggest that companies engage in philanthropic activities for marketing purposes, and thus negatively impact the employer's brand.

\subsection{The Revelation}

Charitable behavior is an important way for enterprises to fulfill their social responsibilities and respond to the call of the third distribution, which is of great significance in narrowing the social gap and promoting the rational distribution of market resources. Employee is an important human resource of enterprise production activities. Employer brand plays an important role in reducing the cost of human resource, attracting potential employees, and improving the engagement and satisfaction of employees. Therefore, enterprises should consider employees' perception when carrying out philanthropic strategic planning, adopt appropriate philanthropic behavior to assist in building a strong employer brand, improve employees' sense of identity with the organization, and build talent base for the sustainable development of enterprises.

This paper provides a new idea for corporate philanthropy strategic planning and employer brand building. In addition, the enterprise should also consider the exposure and evaluation brought by the enterprise's advertising marketing, and masters the degree of advertising investment, so that the good deeds of the enterprise can be repaid.

The limitation of this paper is that due to the incomplete information disclosure of enterprises and the small sample size, future research can combine the information disclosure data and interviews to obtain universal conclusions from the more complete data. On the other hand, the ways of corporate philanthropy are increasingly diversified. This paper only analyzes the two ways of corporate philanthropy, so other ways of philanthropy can be included in future studies to comprehensively analyze the impact of different philanthropic behaviors on employer brands.

\section{ACKNOWLEDGMENT}

This paper is supported by the National Social Science Foundation of China: "Research on the Impact of HumanMachine Cooperative Behaviour Characteristics on Enterprise Human Resource Management System in the Era of Artificial Intelligence" (NSSFC: 19BGL123)

\section{REFERENCES}

[1] Liket, K.; Simaens, A. "Battling the devolution in the research on corporate philanthropy." Journal of Business Ethics, vol.126, pp. 285-308, 2015. 
[2] Zavyalova, E.; Kucherov, D. "Relationship between organizational culture and job satisfaction in Russian business enterprises." Human Resource Development International, vol.13, pp. 225-235, 2010.

[3] Janhonen, M. "The role of the employer brand in employee attraction and retention: case: Matchtech Group PLC.”, 2017.

[4] Gautier, A.; Pache, A.-C. "Research on corporate philanthropy: A review and assessment." Journal of Business Ethics, vol.126, pp. 343-369, 2015.

[5] Breeze, B.; Wiepking, P. "Different Drivers: Exploring employee involvement in corporate philanthropy." Journal of Business Ethics, vol.165, pp. 453-467, 2020.

[6] Lee, Y.-K.; Choi, J.; Moon, B.-y.; Babin, B.J. "Codes of ethics, corporate philanthropy, and employee responses." International Journal of Hospitality Management, vol.39, pp. 97-106, 2014.

[7] Arco-Castro, L.; López-Pérez, M.V.; Pérez-López, M.C.; Rodríguez-Ariza, L. "Corporate philanthropy and employee engagement." Review of Managerial Science, vol.14, pp. 705-725,2020.

[8] Ambler, T.; Barrow, S. "The employer brand." Journal of brand management, vol.4, pp. 185-206, 1996.

[9] Russell, S.; Brannan, M.J. ““'Getting the Right People on the Bus": Recruitment, selection and integration for the branded organization." European Management Journal, vol.34, pp. 114-124, 2016.

[10] Lievens, F.; Highhouse, S. "The relation of instrumental and symbolic attributes to a company's attractiveness as an employer." Personnel psychology, vol.56, pp. 75-102, 2003.

[11] Banerjee, P.; Saini, G.K.; Kalyanaram, G. "The role of brands in recruitment: mediating role of employer brand equity." Asia Pacific Journal of Human Resources, vol.58, pp. 173-196, 2020.
[12] Sivertzen, A.-M.; Nilsen, E.R.; Olafsen, A.H. "Employer branding: employer attractiveness and the use of social media." Journal of Product \& Brand Management, 2013.

[13] Mouton, H.; Bussin, M. "Effectiveness of employer branding on staff retention and compensation expectations." South African Journal of Economic and Management Sciences, vol.22, pp. 1-8, 2019.

[14] Chawla, P. "Impact of employer branding on employee engagement in business process outsourcing (BPO) sector in India: mediating effect of personorganization fit." Industrial and Commercial Training, 2019.

[15] Gaddam, S. "Modeling Employer Branding Communication: The Softer Aspect of HR Marketing Management.” ICFAI Journal of Soft Skills, vol.2, 2008.

[16] Jones, D.A.; Willness, C.R.; Madey, S. "Why are job seekers attracted by corporate social performance? Experimental and field tests of three signal-based mechanisms." Academy of Management Journal, vol.57, pp. 383-404, 2014.

[17] Özcan, F.; Elçi, M. 'Employees' Perception of CSR Affecting Employer Brand, Brand Image, and Corporate Reputation.” SAGE Open, vol.10, 2020.

[18] Nakao, T. "Market share, advertising, R\&D, and profitability: An empirical analysis of leading industrial firms in Japan.” Review of Industrial Organization, vol.8, pp. 315-328, 1993.

[19] Rinallo, D.; Basuroy, S. "Does advertising spending influence media coverage of the advertiser?" Journal of Marketing, vol.73, pp. 33-46, 2009.

[20] Collins, C.J.; Han, J. "Exploring applicant pool quantity and quality: The effects of early recruitment practice strategies, corporate advertising, and firm reputation." Personnel psychology, vol.57, pp. 685-717, 2004. 